\title{
Obesity and prostate cancer: gene expression signature of human periprostatic adipose tissue
}

\author{
Ricardo Ribeiro ${ }^{1,2,3,4^{*}}$, Cátia Monteiro ${ }^{1,4}$, Victoria Catalán ${ }^{3,5}$, Pingzhao Hu ${ }^{6}$, Virgínia Cunha ${ }^{1,4}$, Amaia Rodríguez ${ }^{3,5}$, \\ Javier Gómez-Ambrosi ${ }^{3,5}$, Avelino Fraga ${ }^{1,2,7}$, Paulo Príncipe ${ }^{7}$, Carlos Lobato ${ }^{8}$, Francisco Lobo ${ }^{9}$, António Morais ${ }^{9}$, \\ Vitor Silva ${ }^{9}$, José Sanches-Magalhães ${ }^{9}$, Jorge Oliveira ${ }^{9}$, Francisco Pina ${ }^{10}$, Carlos Lopes ${ }^{2}$, Rui Medeiros ${ }^{1,2,4,11}$ and \\ Gema Frühbeck $3,5,12^{*}$
}

\begin{abstract}
Background: Periprostatic (PP) adipose tissue surrounds the prostate, an organ with a high predisposition to become malignant. Frequently, growing prostatic tumor cells extend beyond the prostatic organ towards this fat depot. This study aimed to determine the genome-wide expression of genes in PP adipose tissue in obesity/ overweight (OB/OW) and prostate cancer patients.

Methods: Differentially expressed genes in human PP adipose tissue were identified using microarrays. Analyses were conducted according to the donors' body mass index characteristics (OB/OW versus lean) and prostate disease (extra prostatic cancer versus organ confined prostate cancer versus benign prostatic hyperplasia). Selected genes with altered expression were validated by real-time PCR. Ingenuity Pathway Analysis (IPA) was used to investigate gene ontology, canonical pathways and functional networks.

Results: In the PP adipose tissue of OB/OW subjects, we found altered expression of genes encoding molecules involved in adipogenic/anti-lipolytic, proliferative/anti-apoptotic, and mild immunoinflammatory processes (for example, FADS1, down-regulated, and LEP and ANGPT1, both up-regulated). Conversely, in the PP adipose tissue of subjects with prostate cancer, altered genes were related to adipose tissue cellular activity (increased cell proliferation/differentiation, cell cycle activation and anti-apoptosis), whereas a downward impact on immunity and inflammation was also observed, mostly related to the complement (down-regulation of (FH). Interestingly, we found that the microRNA MIRLET7A2 was overexpressed in the PP adipose tissue of prostate cancer patients.

Conclusions: Obesity and excess adiposity modified the expression of PP adipose tissue genes to ultimately foster fat mass growth. In patients with prostate cancer the expression profile of PP adipose tissue accounted for hypercellularity and reduced immunosurveillance. Both findings may be liable to promote a favorable environment for prostate cancer progression.
\end{abstract}

Keywords: adipose tissue, gene expression, microarray, obesity, periprostatic, prostate cancer

\section{Background}

Prostate cancer is the most common solid neoplasm and the second cause of cancer death in men in Europe [1]. Age, ethnic background and family history are wellestablished risk factors. In addition, accumulating

\footnotetext{
*Correspondence: oriebir.r@gmail.com; gfruhbeck@unav.es

'Molecular Oncology Group, Portuguese Institute of Oncology, Ed. Laboratórios-Piso 4, Rua Dr. António Bernardino de Almeida 4200-072, Porto, Portugal

${ }^{3}$ Metabolic Research Laboratory, Clínica Universidad de Navarra, Pío XII 36, 31008, Pamplona, Spain

Full list of author information is available at the end of the article
}

evidence over the last years has shown that obesity is a relevant risk factor for many types of malignancies, including aggressive prostate cancer $[2,3]$.

Adipose tissue dysfunctional behavior, often seen in obesity, has been widely appreciated as a major cause underlying cancer [4]. The prostate has a capsular-like structure and is surrounded by adipose tissue. Frequently, prostate tumor cells infiltrate the periprostatic (PP) fat pad by transposing or infiltrating the capsule [5], resulting in immediate proximity to adipose tissue. Once cancer cells extend beyond the capsule, the PP adipose tissue-secreted

\section{Biomed Central}


factors, extracellular matrix components or direct cell-cell contact may influence the phenotypic behavior of malignant cells. In fact, recent findings in PP adipose tissue showed that tumor-derived factors influence its metabolic activity profile, and that increased local production of adipokines and PP fat thickness were associated with prostate cancer aggressiveness [6-9]. Furthermore, while the PP adipose tissue gene expression profile is currently unknown, it is well established that adipose tissue from distinct anatomical origins and obesity status has specific gene expression signatures [10,11]. Knowledge of the PP adipose tissue genomic profile may uncover molecules and mechanisms linked either with obesity or prostate cancer that can influence prostate cancer progression.

In this study, we aimed to determine the spectrum of genes differentially expressed in PP adipose tissue as well as relevant functional clustering, in order to evaluate the influence of obesity/overweight $(\mathrm{OB} / \mathrm{OW})$ on prostate cancer and vice versa.

\section{Methods}

\section{Patients}

Patients scheduled for retropubic radical prostatectomy or partial open prostatectomy between May and October 2009 , without major co-morbidities, were included in this study after they gave informed consent. Inclusion criteria were age ( 45 to 75 years) and absence of previous prostatic treatments. Exclusion criteria were: diabetes, family history of prostate cancer, transvesical partial open prostatectomy, other primary malignancies, or pharmacological treatment with drugs that may modify adipose tissue gene expression (for example, anti-dislipidemics or anti-diabetics).

Anterior-lateral samples of PP adipose tissue were collected during surgery. Adipose tissue samples were immediately sectioned, cleaned and rinsed with pre-warmed PBS and immersed in RNAlater (Applied Biosystems, Foster City, CA, USA).
Eighteen patients participated in the study and were divided into three groups based on post-surgical diagnosis and pathologic analyses. Six patients with benign prostatic hyperplasia $(\mathrm{BPH})$ and twelve with prostate cancer (six with pT1-T2, organ confined prostate cancer (OCPCa) and six with pT3-T4, extra-prostatic prostate cancer (EPCa)) met the criteria for inclusion in this study. In each prostatic disease group, three patients were lean (body mass index, BMI $<25 \mathrm{~kg} / \mathrm{m}^{2}$ ) and three were obese/overweight ( $\mathrm{OB} / \mathrm{OW}, \mathrm{BMI} \geq 25 \mathrm{~kg} / \mathrm{m}^{2}$ ), resulting in overall nine lean and nine OB/OW. Participants' clinicopathological characteristics and serum PSA concentration at diagnosis were reviewed from clinical charts and are presented in Table 1. The project was approved, from an ethical and scientific standpoint, by the Ethical Committees responsible for research at all institutions, namely the Portuguese Institute of Oncology, Porto Hospital Centre and Porto Military Hospital in Portugal, as well as that of the Clínica Universidad de Navarra in Spain. All reported investigations were carried out in accordance with the principles of the Declaration of Helsinki as revised in 2008.

\section{RNA extraction, microarray hybridization and data processing}

Total RNA was extracted from PP adipose tissue samples after homogenization with an ULTRA-TURRAX T25 basic (IKA Werke GmbH, Staufen, Germany) in QIAzol reagent (Qiagen, Valencia, CA, USA) and purified through columns (RNeasy Lipid Tissue Mini kit, Qiagen) with DNase I treatment (RNase-free DNase set, Qiagen). Integrity and purity of RNA were assessed by on-chip electrophoresis using Experion (BioRad, Hercules, CA, USA).

From $1 \mu \mathrm{g}$ total RNA, cDNA and biotin-labeled antisense cRNA were obtained and hybridized to a high-density oligonucleotide human genome array HG-U133 Plus 2.0 Affymetrix GeneChip Arrays (Affymetrix, Santa Clara, CA, USA). Background correction and normalization were done

Table 1 Characteristics of participants included in the study

\begin{tabular}{|c|c|c|c|c|}
\hline & BPH $(n=6)$ & OCPCa $(n=6)$ & EPCa $(n=6)$ & $P$ \\
\hline Age (years) & $67.4 \pm 3.9$ & $59.4 \pm 2.9$ & $66.9 \pm 2.3$ & $0.140^{\mathrm{a}}$ \\
\hline BMI $\left(\mathrm{kg} / \mathrm{m}^{2}\right)$ & $26.5 \pm 1.5$ & $25.2 \pm 1.3$ & $26.5 \pm 1.6$ & $0.783^{\mathrm{a}}$ \\
\hline Serum total PSA (ng/mL) & $8.9 \pm 4.7$ & $6.7 \pm 1.6$ & $14.7 \pm 3.0$ & $0.114^{b}$ \\
\hline Prostate weight (g) & $107.0 \pm 12.9$ & $40.8 \pm 4.2$ & $71.2 \pm 9.5$ & $0.001^{a, c}$ \\
\hline Serum leptin $(\mathrm{mg} / \mathrm{mL})$ & $3.7 \pm 1.0$ & $7.1 \pm 2.5$ & $4.9 \pm 1.8$ & $0.453^{\mathrm{a}}$ \\
\hline \multicolumn{5}{|l|}{ Combined Gleason score } \\
\hline$\leq 7(3+4), \mathrm{n}(\%)$ & - & $5(83 \%)$ & $4(67 \%)$ & $1.000^{\mathrm{d}}$ \\
\hline$\geq 7(4+3), n(\%)$ & - & $1(17 \%)$ & $2(33 \%)$ & \\
\hline
\end{tabular}

Continuous variables are presented as mean \pm SE. ${ }^{a}$ ANOVA for independent measures; ${ }^{b} \mathrm{Kruskal}-$ Wallis test; ${ }^{\mathrm{C} L S D}$ post-hoc analysis: BPH versus organ confined $P C a, P<0.0001, B P H$ versus extra prostatic cancer, $P=0.018$, extra prostatic cancer versus organ confined $P C a, P=0.040 ;{ }^{d}$ Fisher exact test. Median (interquartile range) values for serum total PSA: $\mathrm{BPH}, 4.7$ (3.7 to 18.4$) \mathrm{ng} / \mathrm{mL}$; organ confined cancer, 5.1 (4.1 to 10.2$) \mathrm{ng} / \mathrm{mL}$; extra-prostatic cancer, 14.7 (8.3 to 21.2$) \mathrm{ng} / \mathrm{mL}$. ANOVA, analysis of variance; BMI, body mass index; $\mathrm{BPH}$, benign prostatic hyperplasia; EPCa, extra prostatic cancer; OCPCa, organ confined prostate cancer; PCa, prostate cancer; PSA, prostate specific antigen. 
using a robust multi-array average algorithm [12]. Calculation of fold change values was performed using the lean and the non-cancer or OCPCa as reference. We used Linear Models for Microarray Data [13] to identify differentially expressed genes. Briefly, it starts by fitting a linear model for each gene in the data; then an empirical Bayes method is used to moderate the standard errors for estimating the moderated t-statistics for each gene, which shrinks the standard errors towards a common value. This test is similar to a t-test method for each probe except that the residual standard deviations are moderated across genes to ensure a more stable inference for each gene. The moderated standard deviations are a compromise between the individual genewise standard deviations and an overall pooled standard deviation. We used False Discovery Rate [14] to evaluate the statistical significance of all genes.

\section{Enrichment analysis using Ingenuity Pathway Analysis software}

We evaluated the gene function and network enrichments for selected genes (unadjusted $P<0.01$ ) using Ingenuity Pathway Analysis (IPA) software (Ingenuity Systems, Redwood City, The OCPCa group of patients was not included in this analysis. Human Genome Organisation (HUGO)-approved gene symbols and their corresponding fold change were uploaded into the software. Networks of these genes were algorithmically generated based on their connectivity and assigned a score. The score takes into account the number of focus genes in the network and the size of the network to approximate its relevance to the original list of focus genes. The identified networks are presented as a figure indicating molecular relationships between genes/gene products. Canonical pathway analysis identified the pathways which were more significant to the input data set.

\section{Real-Time PCR}

To validate the microarray data, a number of representative genes and microRNAs were selected to be studied by real-Time PCR. For gene expression analysis, cDNA was generated using the ThermoScript RT-PCR system (Invitrogen, Carlsbad, CA, USA), whereas for microRNA expression we used the Taqman MicroRNA RT kit (Applied Biosystems), according to the manufacturer's instructions.

Transcript levels of the selected genes and microRNAs were quantified by Real-Time PCR (StepOne, Foster City, CA, Applied Biosystems). The cDNA was amplified using the following conditions, both for genes (Taqman Gene Expression Master Mix, Applied Biosystems) and microRNAs (Taqman Universal Master Mix, Applied Biosystems): $95^{\circ} \mathrm{C}$ for 10 minutes, followed by 45 cycles of 15 seconds at $95^{\circ} \mathrm{C}$ and 1 minute at $60^{\circ} \mathrm{C}$. Results were normalized to the levels of the $18 S$ rRNA for genes and of mir-103 for microRNA, according to previous reports using adipose tissue $[15,16]$. Assays' ID are available upon request to the authors. Gene and microRNA expression was calculated using the REST 2009 software, where relative expression was expressed as fold over the reference group. The products of the $P C A 3$ gene amplification were verified by $1.5 \%$ agarose gel electrophoresis, and acquired using the GelDoc XR system (BioRad) and Quantity One software (BioRad).

\section{Plasma leptin measurement}

Plasma samples were obtained before surgery after an overnight fast. The concentrations of circulating leptin were quantified using microsphere-based multiplexing technology, as previously described [17]. The intra- and inter-assay precisions were $4.2 \%$ and $21.4 \%$, respectively. The minimum leptin detectable concentration was $27.4 \mathrm{pg} / \mathrm{mL}$.

\section{Statistical analysis}

Data are presented as mean \pm standard error of the mean or median (interquartile range). Departure from normality was tested using the Kolmogorov-Smirnov test. Accordingly, one-way analysis of variance (ANOVA), Kruskal-Wallis or Fisher tests were used for comparisons of clinicopathological variables between prostatic disease groups, whereas differences between $\mathrm{OB} / \mathrm{OW}$ and lean groups were tested by unpaired t-test, Mann-Whitney and chi-square tests. Data analyses were performed using the software SPSS version 17.0 (SPSS Inc., Chicago, USA) and a $P<0.05$ was considered statistically significant.

\section{Results}

Patient characteristics

Clinicopathological characteristics of participants according to prostatic disease status are presented in Table 1. Age at diagnosis, BMI, serum leptin and prostate specific antigen (PSA) levels, and combined Gleason grade in subjects with cancer were similar between prostatic disease groups ( $P>0.05$ for all comparisons). In this study, as expected, BPH subjects presented heavier prostates $(P<$ 0.05). The OB/OW had higher mean BMI $(29.1 \pm 1.8$ versus $\left.23.1 \pm 1.2 \mathrm{~kg} / \mathrm{m}^{2}, P<0.0001\right)$ and serum leptin levels $(8.6 \pm 1.3$ versus $1.9 \pm 0.7 \mathrm{mg} / \mathrm{mL}, P=0.001)$ than lean subjects. For each group of prostate disease $(\mathrm{BPH}, \mathrm{OCPCa}$ and EPCa), significantly higher BMI was observed in $\mathrm{OB} /$ OW subjects compared with lean individuals $(P=0.016$, $P<0.0001$ and $P=0.013$, respectively)

\section{PCA3 gene expression in PP adipose tissue}

Frequently, prostate tumor cells infiltrate the PP fat; therefore, in order to analyze the PP adipose tissue gene expression signature, we needed to confirm the absence of tumor cells. To confirm whether PP adipose tissue samples were free from prostate cancer cells the expression of the $P C A 3$ 
gene was examined. Lack of expression of this gene in the $\mathrm{PP}$ adipose tissue of cancer patients was demonstrated (Figure 1).

\section{Defining the PP adipose tissue gene expression signature in $\mathrm{OB} / \mathrm{OW}$ subjects}

Comparison of overall transcriptional response revealed 148 of the analyzed gene probe sets as significantly changed $(P<0.001$ and absolute fold change $\geq 1.5)$. Among these gene probe sets, gene expression features of the overall $\mathrm{OB} / \mathrm{OW}$ patients associated with six altered genes, whereas $\mathrm{OB} / \mathrm{OW}$ subjects in restricted $\mathrm{BPH}, \mathrm{OCPCa}$ and EPCa groups exhibited a specific panoply of altered genes for each condition, which is summarized in Table 2 showing the most representative ones (Table 2).

The IPA software was used to investigate functions and interactions among altered genes. This analysis revealed a broad spectrum of biological processes for $\mathrm{OB} / \mathrm{OW}$ versus lean. Altered functions were predominantly related to nutritional disease, connective tissue development and function, cell death, cellular development and cellular growth and proliferation [See Additional file 1, Table S1]. Additional file 2 Figure $\mathrm{S} 1$ ) shows the most significant network in $\mathrm{OB} / \mathrm{OW}$ men $(P<0.0001)$. In human PP adipose tissue of $\mathrm{OB} / \mathrm{OW}$ the most relevantly altered canonical pathways were associated with glycerolipid metabolism and leptin signaling (Table 3), and differentially expressed genes encoded proteins involved in immunity and inflammation, cell growth and proliferation, fat metabolism and apoptosis. When restricted to the group of subjects with $\mathrm{BPH}$, being $\mathrm{OB} / \mathrm{OW}$ was associated with changes in the expression of genes involved in cell-to-cell signaling, tissue development and cellular movement functions [See Additional file 1, Table S1].

\section{Defining the PP adipose tissue gene expression signature in prostate cancer patients}

Table 4 shows differentially expressed genes according to prostatic disease $(P<0.001$ and absolute fold change $\geq 1.5)$. We found that in the PP adipose tissue of EPCa patients eight genes were up-regulated compared to $\mathrm{BPH}$, while in OCPCa versus BPH most of the genes were down-regulated; a predominance of up-regulated genes was observed in EPCa compared to OCPCa. The PP adipose tissue of cancer patients exhibited increased transcript levels of MIRLET7A2 and TC2N compared with BPH. Interestingly, MIRLET7A2 and MRPL42 were overexpressed in all analyses (overall, and within lean and OB/OW groups) in the PP adipose tissue of patients with EPCa. In OB/OW subjects three genes were consistently overexpressed (TC2N, MIRLET7A2 and CLDN10) in the PP adipose tissue of men with cancer (EPCa or OCPCa), compared to $\mathrm{BPH}$

In the analysis of prostate cancer versus $\mathrm{BPH}, \mathrm{OB} / \mathrm{OW}$ subjects presented more altered genes in PP adipose tissue. The IPA analysis identified interaction networks between EPCa versus $\mathrm{BPH}$ and found that functions were more frequently related to cellular growth and proliferation, cell cycle, apoptosis and cell death, cellular movement and to inflammation and immunity [See Additional file 3, Table S2] $(P<0.0001)$. The altered canonical pathways $(P<0.05)$ in the PP adipose tissue of EPCa are shown in Table 3.

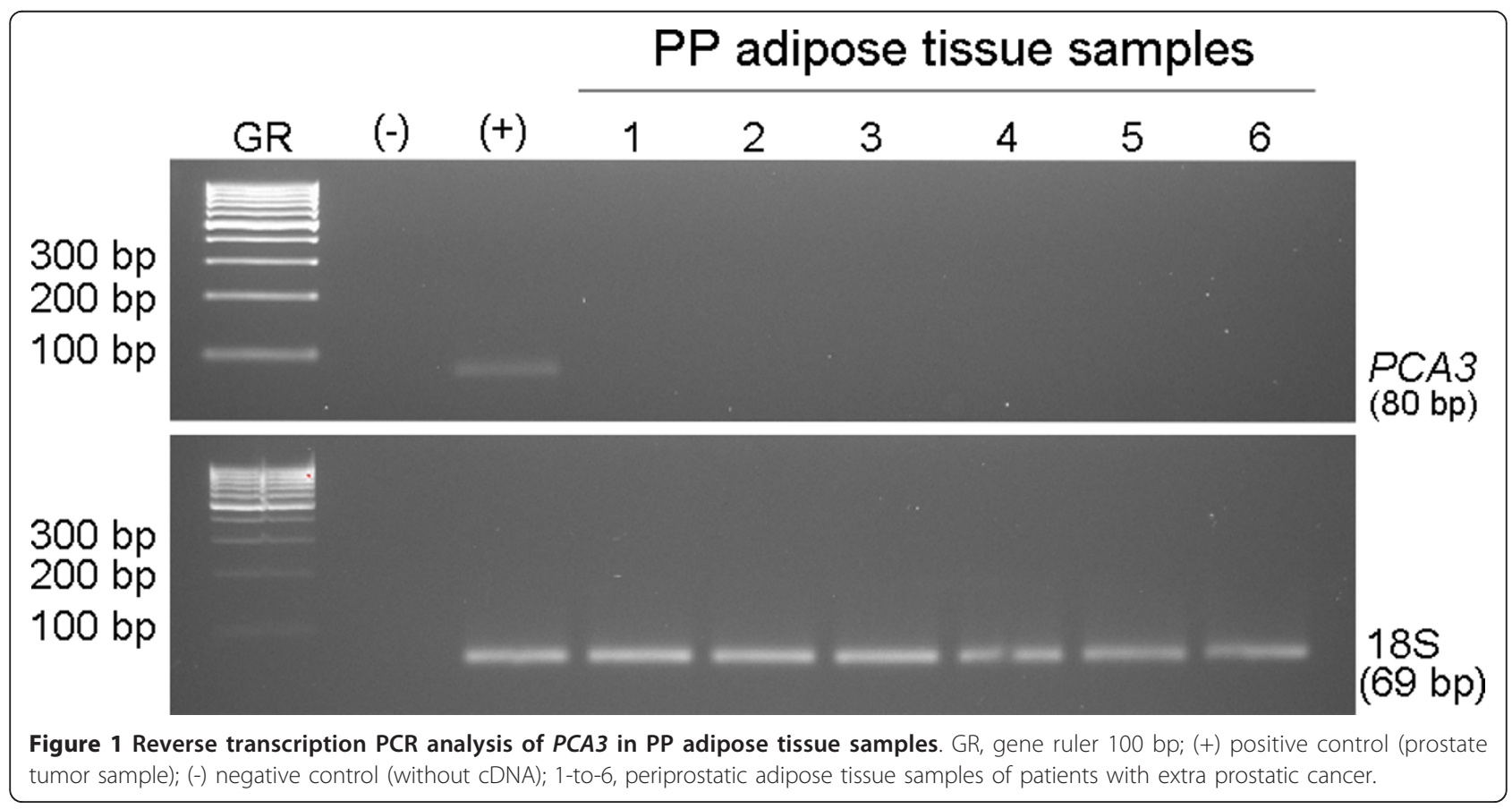


Table 2 Altered genes in microarray analysis in OB/OW PP adipose tissue (overall and by prostatic disease)

\begin{tabular}{|c|c|c|c|c|}
\hline Probe set & Gene Name & Gene Description & Fold Change & $P$ \\
\hline \multicolumn{5}{|l|}{ All subjects } \\
\hline 8098146 & NPY5R & neuropeptide $Y$ receptor $Y 5$ & 1.80 & 1.49E-05 \\
\hline 7948612 & FADS1 & fatty acid desaturase 1 & -1.73 & 1.16E-04 \\
\hline 8103494 & NPY1R & neuropeptide $Y$ receptor $Y 1$ & 1.97 & 1.56E-04 \\
\hline 7969050 & CYSLTR2 & cysteinyl leukotriene receptor 2 & 1.89 & 2.19E-04 \\
\hline 8073633 & PNPLA3 & patatin-like phospholipase domain containing 3 & -1.56 & 5.74E-04 \\
\hline 7930181 & AS3MT & arsenic ( +3 oxidation state) methyltransferase & 1.53 & $6.54 \mathrm{E}-04$ \\
\hline \multicolumn{5}{|l|}{$\mathrm{BPH}$} \\
\hline 8020343 & ANKRD20A5 & ankyrin repeat domain 20 family; member A5 & -1.51 & 3.95E-05 \\
\hline 8152297 & ANGPT1 & angiopoietin 1 & 1.63 & 2.08E-04 \\
\hline 7937508 & CD151 & CD151 molecule (Raph blood group) & 1.69 & 2.43E-04 \\
\hline 7959102 & HSPB8 & heat shock 22kDa protein 8 & 1.51 & $3.88 \mathrm{E}-04$ \\
\hline 8047780 & SNORA41 & small nucleolar RNA; H/ACA box 41 & -1.77 & 4.94E-04 \\
\hline 8098146 & NPY5R & neuropeptide $Y$ receptor $Y_{5}$ & 2.06 & 7.86E-04 \\
\hline 8135909 & LEP & leptin & 1.95 & 8.00E-04 \\
\hline \multicolumn{5}{|l|}{$\overline{\mathrm{OCPCa}}$} \\
\hline 7997239 & PDXDC2 & pyridoxal-dependent decarboxylase domain containing 2 & 1.99 & $8.30 \mathrm{E}-06$ \\
\hline 7994026 & NPIPL3 & nuclear pore complex interacting protein-like 3 & 1.64 & $1.52 \mathrm{E}-04$ \\
\hline 8019280 & PCYT2 & phosphate cytidylyltransferase 2; ethanolamine & -1.54 & 7.55E-04 \\
\hline \multicolumn{5}{|l|}{ EPCa } \\
\hline 7902400 & SNORD45B & small nucleolar RNA; C/D box 45B & -4.71 & 2.29E-04 \\
\hline 7980861 & CATSPERB & cation channel; sperm-associated; beta & 1.73 & 5.81E-04 \\
\hline 8057004 & PDE11A & phosphodiesterase 11A & 2.59 & $6.68 \mathrm{E}-04$ \\
\hline 8004325 & EIF5A & eukaryotic translation initiation factor $5 \mathrm{~A}$ & -1.50 & $7.72 \mathrm{E}-04$ \\
\hline 7969050 & CYSLTR2 & cysteinyl leukotriene receptor 2 & 2.50 & $9.01 \mathrm{E}-04$ \\
\hline
\end{tabular}

Fold change and the corresponding $P$-value for each significant gene are presented, using the lean group as reference. The bold ones with adjusted $P<0.2$.

\section{Validation of selected genes by real-time PCR}

Validation experiments were performed to confirm the accuracy of array gene expression measurements. We selected a set of representative transcripts involved in cell proliferation, immunity and lipid metabolism. Results across the 18 study patients are shown in Figure 2. Overall, PCR results reflected the findings of microarrays.

\section{Discussion}

Extra-capsular extension of prostate cancer cells into the $\mathrm{PP}$ adipose tissue is a common pathologic finding and a factor related with worst prognosis [5]. Once tumor cells extend beyond the prostatic capsule, the interactions with non-tumor cells in the PP adipose tissue may influence its phenotypic behavior. In fact, accumulating evidence shows that the microenvironment is decisive in determining whether cancer cells progress towards metastasis or whether they remain dormant [18]. To date, the scarce reports on PP adipose tissue support a mechanistic link with prostate cancer aggressiveness [6-9].

In the present study, $46 \%$ of the well-characterized genes included in the array were expressed at detection level in $\mathrm{PP}$ adipose tissue, which is comparable to omental adipose tissue [11]. The comparison of PP adipose tissue gene expression of non-diabetic $\mathrm{OB} / \mathrm{OW}$ men to lean men with prostatic disease identified, for the first time, 34 differentially expressed genes of which we focused our attention on 20 as the most relevant ones.

Two important but opposed pathways, lipolysis and adipo/lipogenesis, have a significant role in energy balance. In our study, consistent with other reports on visceral adipose tissue [11], altered expression of genes involved in lipolysis were found in association with obesity and excess adiposity. NPY1R and NPY5R have anti-lipolytic effects [19], whereas LEP expression relates to adipo/lipogenesis despite leptin being also a lipolytic factor [20], with all of these overexpressed genes being in the PP adipose tissue of OB/OW men. Noteworthy, PDE11, which has been shown to be involved in adipocyte differentiation and cyclic nucleotides biology [21], was overexpressed in PP adipose tissue of OB/OW subjects. Downstream effects of altered genes reportedly up-regulate adipo/lipogenesis, including PNPLA3 (also known as adiponutrin), which encodes a triacylglycerol lipase that mediates triacylglycerol hydrolysis [22], FADS1, that regulates unsaturation of fatty acids and SREBP-1 expression [23] or PCYT2, that mediates phosphatidylethanolamine synthesis and the availability of di- and triacylglycerol [24]. The combined 
Table 3 Significant canonical pathways $(P<0$

\begin{tabular}{|c|c|}
\hline Pathway & $-\log _{10}(P)$ \\
\hline \multicolumn{2}{|l|}{ All (OB/OW versus lean) } \\
\hline Glycerolipid metabolism & 2.20 \\
\hline Lysine degradation & 2.08 \\
\hline Leptin signaling in obesity & 1.78 \\
\hline \multicolumn{2}{|l|}{$\mathrm{BPH}$ (OB/OW versus lean) } \\
\hline ERK5 signaling & 2.31 \\
\hline$\beta$-alanine metabolism & 1.83 \\
\hline AMPK signaling & 1.81 \\
\hline Parkinson's signaling & 1.77 \\
\hline $\mathrm{C}_{21}$-steroid hormone metabolism & 1.77 \\
\hline \multicolumn{2}{|l|}{ EPCa (OB/OW versus lean) } \\
\hline Histidine metabolism & 1.91 \\
\hline Eicosanoid signaling & 1.77 \\
\hline Linoleic acid metabolism & 1.73 \\
\hline \multicolumn{2}{|l|}{ All (EPCa versus BPH) } \\
\hline Antigen presentation pathway & 3.11 \\
\hline Aminosugars metabolism & 2.09 \\
\hline B cell development & 1.81 \\
\hline OX40 signaling pathway & 1.77 \\
\hline ERK5 signaling & 1.59 \\
\hline p53 signaling & 1.55 \\
\hline \multicolumn{2}{|l|}{ Lean (EPCa versus BPH) } \\
\hline T helper cell differentiation & 2.24 \\
\hline Galactose metabolism & 1.68 \\
\hline Hereditary breast cancer signaling & 1.62 \\
\hline $\begin{array}{l}\text { Role of osteoblasts, osteoclasts and condrocytes in } \\
\text { rheumatoid arthritis }\end{array}$ & 1.51 \\
\hline \multicolumn{2}{|l|}{ OB/OW (EPCa versus BPH) } \\
\hline Synaptic long term depression & 2.89 \\
\hline Urea cycle and metabolism of aminogroups & 2.10 \\
\hline p53 signaling & 2.10 \\
\hline Amyothropic lateral sclerosis signaling & 2.02 \\
\hline Aminosugars metabolism & 1.89 \\
\hline Extrinsic prothrombin activation pathway & 1.73 \\
\hline p70S6K signaling & 1.68 \\
\hline Cardiac $\beta$-adrenegic signaling & 1.51 \\
\hline
\end{tabular}

$\mathrm{BPH}$, benign prostatic hyperplasia; $\mathrm{EPCa}$, extra prostatic cancer; OB/OW, obese/overweight.

functional dysregulation of these genes suggests that PP adipose tissue from obese men exhibits an anti-lipolytic and adipo/lipogenic gene expression profile.

The number and volume of adipocytes are determinants of fat mass, while proliferation/differentiation and apoptosis influence adipose tissue growth and regression. In our study, the anti-apoptotic genes ANGPT1 and $H S P B 8$ were up-regulated in PP adipose tissue of $\mathrm{OB} / \mathrm{OW}$ subjects $[25,26]$. Furthermore, the expression of EIF5A, known to activate the intrinsic mitochondrial pathway [27], was repressed in OB/OW men. Besides altered genes in apoptosis pathways, we found an increased expression of genes involved in cell growth and differentiation, such as LEP and ANGPT1, whose products increase endothelial, mesenchymal and tumor cell growth and differentiation [25,28-30], and NPY1R that mediates a proliferative stimulus in progenitor adipose cells [31]. The data presented here suggest an increased cell growth and anti-apoptosis, extensive to endothelial, progenitor or adult lineages in the PP adipose tissue of $\mathrm{OB} / \mathrm{OW}$ men.

Taken together, these anti-lipolytic, adipo/lipogenic, proliferative and anti-apoptotic effects in the PP adipose tissue of $\mathrm{OB} / \mathrm{OW}$ men likely result in fat mass expansion, conferring increased capacity for enlarged adipocytes to express adipokines and increase fatty acid supplies [32,33], which might impact the local energy and availability of growth factors, thereby causing the local environment to allow cancer progression. This environment in the PP adipose tissue of $\mathrm{OB} / \mathrm{OW}$ men may, at least partially, explain the described association of obesity and excess adiposity with the progression of prostate cancer [3] (Figure 3). In addition to a local paracrine effect of adipose tissue-derived factors, obesity-related systemic factors may also influence the development of an aggressive phenotype [34].

Recent developments in obesity and cancer immunological pathways suggest a previously unappreciated complexity of cancer cell-adipose tissue cell-immunoinflammatory cell cross-talk [35]. We found altered genes in PP adipose tissue of $\mathrm{OB} / \mathrm{OW}$ men that are involved in immunity and inflammation. Overexpressed genes engaged in innate and adaptive components of the immune system, include $L E P$, that up-regulates both innate and adaptive immunoinflammatory response [36], NPY1R, that has been shown to inhibit $\mathrm{T}$ cell activation [37], and CYSTLR2, that increases pro-inflammatory cytokine expression [38]. FADS1, known to mediate the formation of inflammatory mediators (for example, prostaglandin E2, PGE2, thromboxane A2, TXA2, and leukotriene B4, LTB4) [39], and EIF5A that is essential for NOS2 translation [40], are both downregulated in the PP adipose tissue of OB/OW men. Thus, the enhanced local mild immunoinflammatory environment, observed in PP adipose tissue of OB/OW men might further influence tissue remodeling and contribute towards tumor progression.

The LEP and ANGPT1 encoded proteins may have roles beyond adipose tissue itself. Prostate cancers express the leptin receptor [41] and leptin staining is significantly increased in malignant prostates and poorly differentiated tumors [41]. Also angiopoietin 1 and its receptor Tie-2 were found in both prostate tumor cells and capillaries [42], where they can induce sprouting angiogenesis [43]. These findings along with our own suggest that PP adipose tissue may modulate prostate cancer progression via production of growth factors that favor proliferative and angiogenic events that in turn are needed for tumor development. 
Table 4 Altered genes in microarray according to prostatic disease status (overall, OB/OW or lean group)

\begin{tabular}{|c|c|c|c|c|}
\hline Probe set & Gene Name & Gene Description & Fold Change & $P$ \\
\hline \multicolumn{5}{|c|}{ Extra Prostatic Cancer versus Benign Prostatic Hyperplasia } \\
\hline \multicolumn{5}{|c|}{ All subjects } \\
\hline 7952313 & MIRLET7A2 & microRNA let-7a-2 & 2.00 & 4.26E-06 \\
\hline 7957540 & MRPL42 & mitochondrial ribosomal protein L42 & 1.63 & $5.49 \mathrm{E}-06$ \\
\hline 7980891 & $T C 2 N$ & tandem C2 domains; nuclear & 2.25 & 8.26E-06 \\
\hline 7915468 & $C C D C 23$ & coiled-coil domain containing 23 & 1.70 & $1.93 \mathrm{E}-05$ \\
\hline 8002020 & TPPP3 & tubulin polymerization-promoting protein family member 3 & 1.66 & $8.62 \mathrm{E}-05$ \\
\hline 7980861 & CATSPERB & cation channel; sperm-associated; beta & 1.84 & $1.48 \mathrm{E}-04$ \\
\hline 7964927 & TSPAN8 & tetraspanin 8 & 1.91 & $2.31 \mathrm{E}-04$ \\
\hline 8168463 & FGF16 & fibroblast growth factor 16 & 1.67 & 2.93E-04 \\
\hline \multicolumn{5}{|c|}{ Lean subjects } \\
\hline 7952313 & MIRLET7A2 & microRNA let-7a-2 & 2.12 & 9.04E-05 \\
\hline 8024485 & GADD45B & growth arrest and DNA-damage-inducible; beta & -1.56 & 9.47E-04 \\
\hline 7957540 & MRPL42 & mitochondrial ribosomal protein $L 42$ & 1.60 & 9.86E-04 \\
\hline \multicolumn{5}{|c|}{ OB/OW subjects } \\
\hline 7980861 & CATSPERB & cation channel; sperm-associated; beta & 2.50 & $1.91 \mathrm{E}-06$ \\
\hline 7980891 & $T C 2 N$ & tandem C2 domains; nuclear & 2.98 & 4.31E-06 \\
\hline 7908488 & CFHR1 & complement factor H-related 1 & 1.88 & $3.16 \mathrm{E}-05$ \\
\hline 8078529 & STAC & SH3 and cysteine rich domain & 1.50 & 5.79E-05 \\
\hline 7902400 & SNORD45B & small nucleolar RNA; C/D box 45B & -5.18 & $1.9 \mathrm{E}-04$ \\
\hline 7908459 & $\mathrm{CFH}$ & complement factor $\mathrm{H}$ & 1.70 & $3.0 \mathrm{E}-04$ \\
\hline 7952313 & MIRLET7A2 & microRNA let-7a-2 & 1.88 & 4.0E-04 \\
\hline 7957540 & MRPL42 & mitochondrial ribosomal protein $L 42$ & 1.65 & 4.0E-04 \\
\hline 7958019 & DRAM1 & DNA-damage regulated autophagy modulator 1 & 1.55 & $5.3 \mathrm{E}-04$ \\
\hline 7969640 & CLDN10 & claudin 10 & 1.59 & $6.3 \mathrm{E}-04$ \\
\hline 8076586 & SCUBE1 & signal peptide; CUB domain; EGF-like 1 & -1.73 & $7.2 \mathrm{E}-04$ \\
\hline 8027862 & FFAR2 & free fatty acid receptor 2 & -1.58 & $9.2 \mathrm{E}-04$ \\
\hline
\end{tabular}

Organ Confined Prostate Cancer versus Benign Prostatic Hyperplasia

All subjects

\begin{tabular}{|c|c|c|c|c|}
\hline 7919349 & RNU1-1 & RNA; U1 small nuclear 1 & -2.18 & $1.50 \mathrm{E}-07$ \\
\hline 7919576 & RNU1-1 & RNA; U1 small nuclear 1 & -1.96 & 2.47E-07 \\
\hline 7952313 & MIRLET7A2 & microRNA let-7a-2 & 1.79 & $6.21 \mathrm{E}-05$ \\
\hline 7980891 & TC2N & tandem C2 domains; nuclear & 1.98 & $6.26 \mathrm{E}-05$ \\
\hline 7978568 & RNU1-1 & RNA; U1 small nuclear 1 & -1.65 & $9.43 \mathrm{E}-05$ \\
\hline 7981964 & SNORD116-8 & small nucleolar RNA; C/D box 116-8 & -1.91 & 1.07E-04 \\
\hline 8004184 & XAF1 & XIAP associated factor 1 & -1.64 & 8.67E-04 \\
\hline \multicolumn{5}{|c|}{ Lean subjects } \\
\hline 8001067 & HERC2P4 & hect domain and RLD 2 pseudogene 4 & -1.77 & $1.22 \mathrm{E}-06$ \\
\hline 7997239 & PDXDC2 & pyridoxal-dependent decarboxylase domain containing 2 & -2.12 & 2.69E-06 \\
\hline 8000692 & BOLA2 & bolA homolog 2 (E, coli) & -1.52 & 3.41E-06 \\
\hline 8000651 & SMG1 & SMG1 homolog; phosphatidylinositol 3-kinase-related kinase (C. elegans) & -1.61 & $3.76 \mathrm{E}-06$ \\
\hline 8019655 & $T B C 1 D 3 B$ & TBC1 domain family; member 3B & -1.56 & $1.26 \mathrm{E}-05$ \\
\hline 7919349 & RNU1-1 & RNA; U1 small nuclear 1 & -2.30 & 2.27E-05 \\
\hline 7927513 & FAM21C & family with sequence similarity 21 ; member $C$ & -1.66 & 2.31E-05 \\
\hline 7993359 & NPIP & nuclear pore complex interacting protein & -1.53 & 4.30E-05 \\
\hline 8014633 & TBC1D3 & TBC1 domain family; member 3 & -1.55 & $5.53 \mathrm{E}-05$ \\
\hline 8014437 & TBC1D3G & TBC1 domain family; member 3G & -1.51 & 6.27E-05 \\
\hline 7994026 & NPIPL3 & nuclear pore complex interacting protein-like 3 & -1.69 & $9.02 \mathrm{E}-05$ \\
\hline \multicolumn{5}{|c|}{ OB/OW subjects } \\
\hline 7969640 & CLDN10 & claudin 10 & 2.01 & 7.04E-06 \\
\hline 7980891 & TC2N & tandem C2 domains; nuclear & 2.31 & 1.10E-04 \\
\hline
\end{tabular}


Table 4 Altered genes in microarray according to prostatic disease status (overall, OB/OW or lean group) (Continued)

\begin{tabular}{|c|c|c|c|c|}
\hline 7952313 & MIRLET7A2 & microRNA let-7a-2 & 2.06 & 1.74E-04 \\
\hline 8021101 & HAUS1 & HAUS augmin-like complex; subunit 1 & 1.61 & 3.10E-04 \\
\hline 8165698 & MIR1977 & microRNA 1977 & -3.03 & 3.46E-04 \\
\hline 8060854 & PLCB1 & phospholipase C; beta 1 (phosphoinositide-specific) & 1.53 & 5.95E-04 \\
\hline \multicolumn{5}{|c|}{ Extra Prostatic Cancer versus Organ Confined Prostate Cancer } \\
\hline \multicolumn{5}{|c|}{ All subjects } \\
\hline 7919349 & RNU1-1 & RNA; U1 small nuclear 1 & 1.71 & 1.86E-05 \\
\hline 7981964 & SNORD116-8 & small nucleolar RNA; C/D box 116-8 & 1.88 & 1.85E-04 \\
\hline 7940287 & MS4A1 & membrane-spanning 4-domains; subfamily A; member 1 & -2.15 & 2.74E-04 \\
\hline \multicolumn{5}{|c|}{ Lean subjects } \\
\hline 8001067 & HERC2P4 & hect domain and RLD 2 pseudogene 4 & 2.06 & 5.14E-08 \\
\hline 8000692 & BOLA2 & bolA homolog 2 (E, coli) & 1.52 & 3.37E-06 \\
\hline 7997239 & PDXDC2 & pyridoxal-dependent decarboxylase domain containing 2 & 2.00 & $6.36 \mathrm{E}-06$ \\
\hline 8000651 & SMG1 & SMG1 homolog; phosphatidylinositol 3-kinase-related kinase (C. elegans) & 1.57 & $6.75 \mathrm{E}-06$ \\
\hline 7927513 & FAM21C & family with sequence similarity 21 ; member $C$ & 1.74 & 8.44E-06 \\
\hline 7993359 & NPIP & nuclear pore complex interacting protein & 1.51 & $5.38 \mathrm{E}-05$ \\
\hline 7994026 & NPIPL3 & nuclear pore complex interacting protein-like 3 & 1.73 & 5.61E-05 \\
\hline 8119595 & RPL7L1 & ribosomal protein L7-like 1 & 1.63 & 5.71E-05 \\
\hline 7990943 & GOLGA6L10 & golgin A6 family-like 10 & 1.55 & $6.08 \mathrm{E}-05$ \\
\hline 7919349 & RNU1-1 & RNA; U1 small nuclear 1 & 1.93 & 2.25E-04 \\
\hline \multicolumn{5}{|c|}{ OB/OW subjects } \\
\hline 7980861 & CATSPERB & cation channel; sperm-associated; beta & 1.78 & $2.92 \mathrm{E}-04$ \\
\hline 7982006 & SNORD116-29 & small nucleolar RNA; C/D box 116-29 & 1.77 & $5.84 \mathrm{E}-04$ \\
\hline
\end{tabular}

The bold ones with adjusted $P<0.2$

Herein, we showed that the PP adipose tissue gene expression profile of $\mathrm{OB} / \mathrm{OW}$ subjects may contribute to increased local adiposity, a mild immunoinflammatory environment and production of molecules with oncogenic potential (Figure 3).

The PP adipose tissue gene expression signature of men with prostate cancer was determined, in order to determine if functional alterations are associated with prostate cancer besides the previously reported PP thickness and protein measurements [9-12]. In the present study, when the PP adipose tissues of age- and BMI-matched nondiabetic men with different prostatic diseases were compared, 119 altered genes were found. Representative genes and functions are shown in Figure 4. Noteworthy, our findings reveal that altered gene networks pertain to cell cycle and proliferation regulation. Overexpressed genes in the PP adipose tissue of cancer patients that are involved in cell cycle and proliferation include PLCB1, that modulates cyclin D3 and CDK4 in response to the IGF-1 mitogenic stimulus [44] or TPPP3, that regulates G2-M and G1-S transitions [45]. Furthermore, HAUS1, a component of the augmin complex involved in spindle microtubule generation in mitosis [46] and TSPAN8 (also known as CO-029), that encodes for an integrin-binding glycoprotein that stimulates endothelial cell proliferation [47], are also up-regulated in cancer patients. Noteworthy, the FGF16 gene that encodes a mitogenic growth factor [48] was overexpressed in the PP adipose tissue of men with prostate cancer. These findings, together with the downregulation of $X A F 1$, which influences $\mathrm{G} 2 / \mathrm{M}$ arrest through modulation of checkpoint kinase 1 and $\mathrm{Cdc} 2$-cyclin $\mathrm{B}$ complex [49], support a positive cell cycle regulation and a permissive stimulus for growth and proliferation in PP adipose tissue cells. Cumulatively, pro-apoptotic genes, such as $X A F 1$ and $G A D D 45 B$ [50,51] were down-regulated, whereas DRAM1 was up-regulated in the adipose tissue of prostate cancer patients [52]. Canonical analysis showed involvement of the p53 pathway in adipose tissue of cancer subjects, possibly reflecting the relationship of the altered genes XAF1, DRAM1 and SMG1 with the p53 pathway. In adipose tissue biology, cell differentiation also plays an important role in increasing fat mass. Here we show altered expression of genes that associate with cellular differentiation of overall (for example, $P L C B 1$, GADD45B), adipocyte (for example, PLCB1, FFAR2) and endothelial lineages (for example, SCUBE1) [44]. Thus, particularly the adipocyte and vascular biology of PP adipose tissue seems to be committed towards the differentiated state in men with prostate cancer. Consistent with gene expression findings, we observed overexpression of the microRNA MIRLETA2 in the PP adipose tissue of prostate cancer patients. The involvement of the let-7 microRNA in adipocyte differentiation has been described earlier [53]. Moreover, canonical pathways analysis showed 


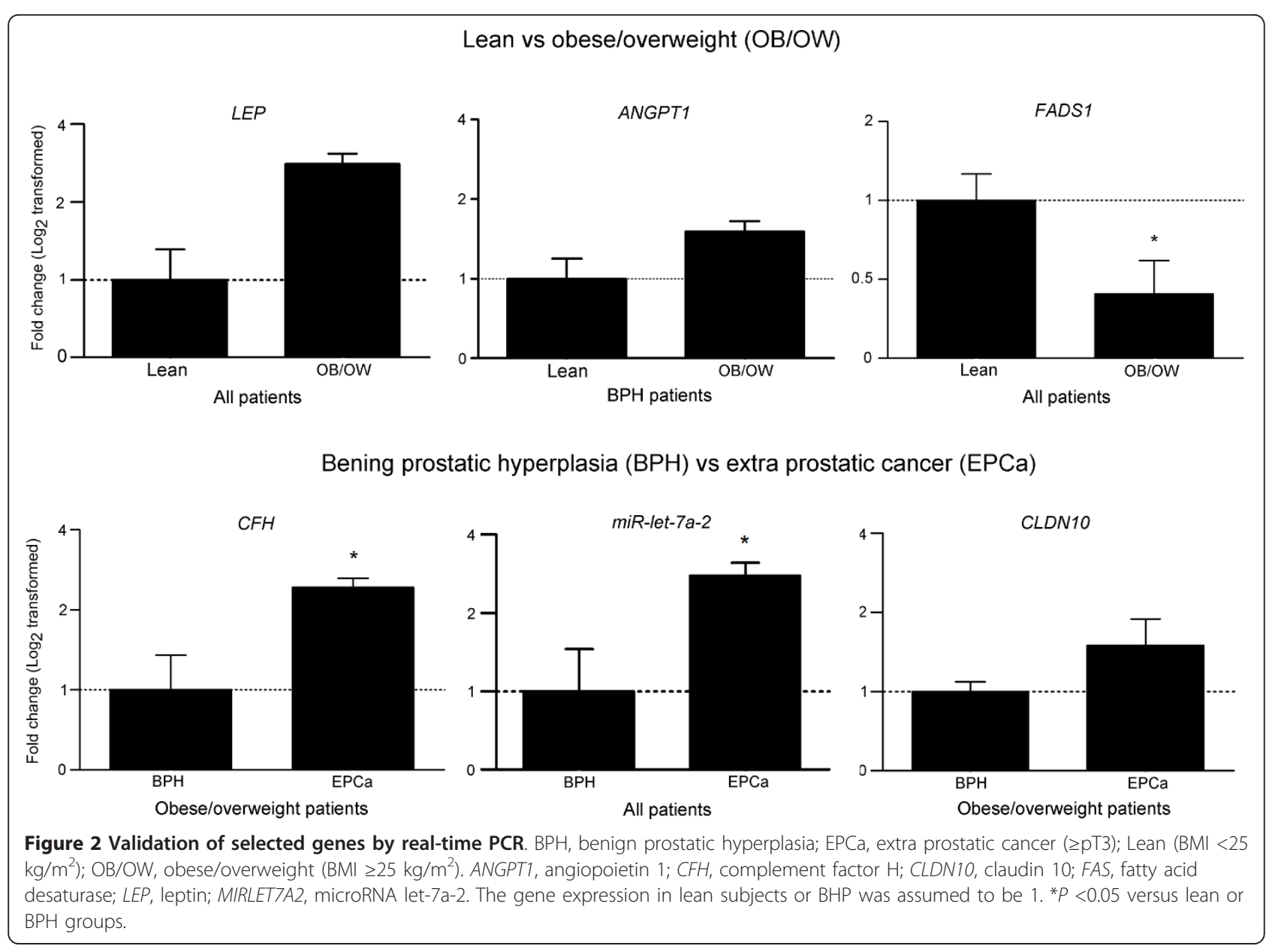

that ERK5 signaling, an evolutionary conserved pathway involved in hypertrophic signaling that regulates adipogenic differentiation [54], was altered in PP adipose tissue of cancer patients. Previously, in vitro studies showed that tumor-derived factors induce preadipocyte differentiation [55], supporting a tumor-educated regulation of the adipose tissue differentiation program. Taken together, the impact of these gene expression results on cell cycle and proliferation, in apoptosis and differentiation of PP adipose tissue cellular components, supports fat mass accrual, which agrees with findings showing increased PP fat pad thickness in prostate cancer patients [6]. Furthermore, bulky adipocytes predispose to increased adipokine secretion and availability of fatty acids, which may influence prostate cancer progression [32,33].

Immunoinflammatory mechanisms drive both obesity and cancer. Canonical analysis showed that the PP adipose tissue of prostate cancer patients presents altered pathways associated with immunity and inflammation, including antigen presentation, B cell development and T helper cell differentiation. The complement system is important in immunosurveillance against tumors, albeit malignant cells are usually resistant to complement-mediated lysis [56]. The products of $C F H$ and CFHR 1 are soluble complement regulators essential for preventing complement activation and, therefore, responsible for complement inhibition [56]. Interestingly, we and others report on the expression of $C F H$ and $C F H R 1$ in adipose tissue [57]. The finding of $C F H$ and $C F H R 1$ up-regulation in PP adipose tissue of subjects with prostate cancer suggests increased inhibitory modulation of the complement activity in prostate tumor cells and evasion to attack. Other altered genes in the PP adipose tissue of prostate cancer patients with repercussion in the local immunoinflammatory environment include $M S 4 A 1$ (also known as CD20) that plays a functional role in B-cell activation [58] and FFAR2 that encodes a protein reported to modulate the differentiation and/or activation of leukocytes [59]. Taken together, these altered genes in PP adipose tissue might contribute to an environment with immunological cellular dormancy and reduced immunosurveillance, which may facilitate prostate cancer progression (Figure 4).

In the present study, we found increased CLDN10 mRNA transcript abundance in the PP adipose tissue of 


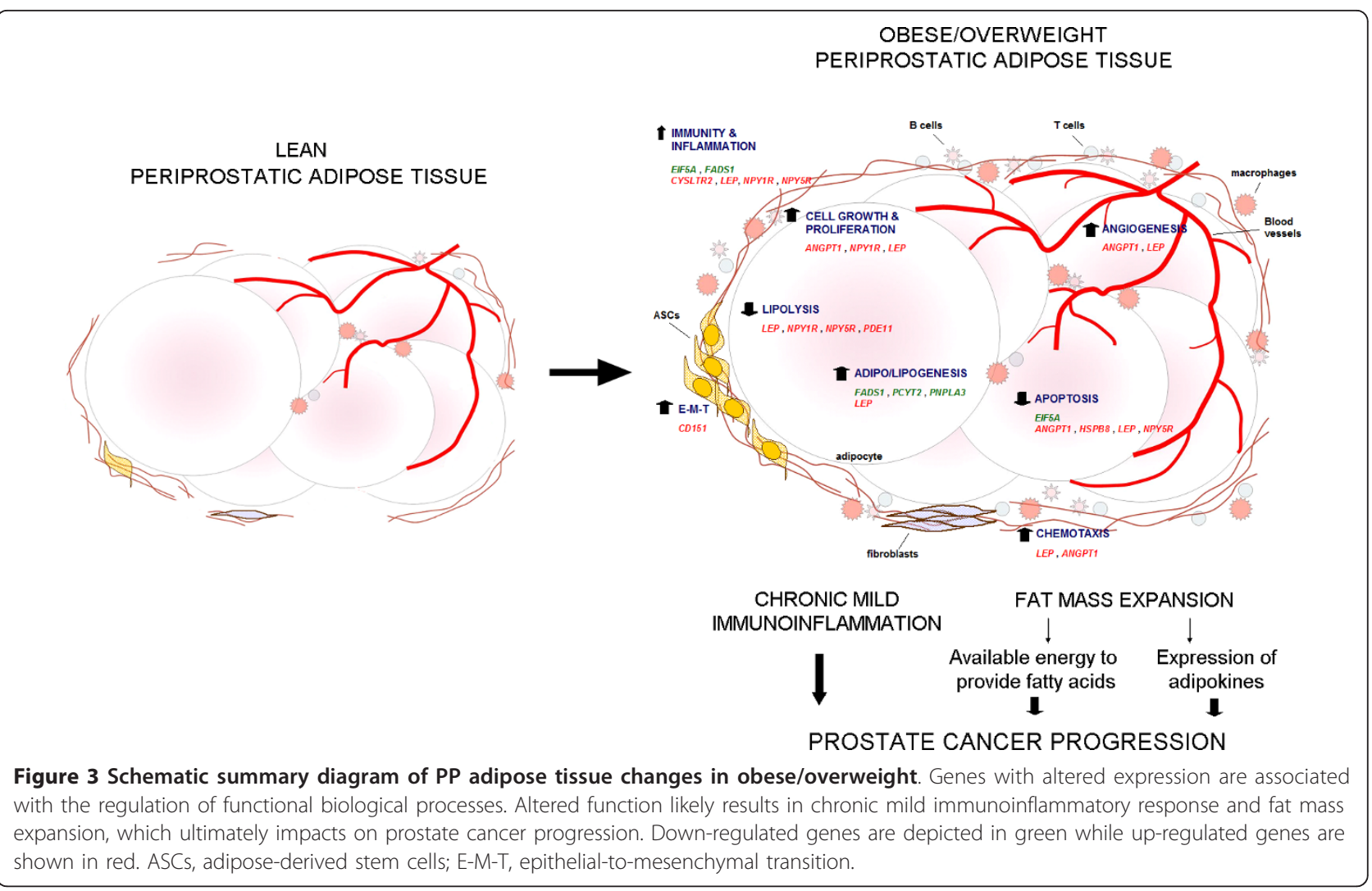

prostate cancer patients using both microarray and realtime PCR analyses. To the best of our knowledge CLDN10 expression in adipose tissue has not been previously reported. This gene encodes an important tight junction component with an intriguing role in adipose tissue considering its functions in the stroma arrangement and cellular connections [60]. Further studies are required to obtain insight regarding the cells involved and the functional implications of CLDN10 expression in PP adipose tissue.

A global gene expression profiling in PP adipose tissue has been applied for the first time in the present study to unravel genes and regulatory pathways associated with $\mathrm{OB} / \mathrm{OW}$ and with prostate cancer. Subjects included in this study had histopathological confirmation of prostatic disease, pathology tumor grade and stage, while contamination with prostate tumor cells in the collected PP adipose tissue samples was excluded by the absence of PCA3 expression. The high-quality GeneChip data set from RNA specimens of PP adipose tissue, careful patient selection for matching by age, race, BMI and clinical variables underscore the strength of the major findings of this study. However, further research is warranted to uncover the PP adipose tissue gene expression profile in association with distinct obesity grades.

Our findings likely represent the effects of excess adiposity or cancer and the bi-directional interactions between all cell types that influence adipose tissue function and might affect or be influenced by prostate cancer progression. These hypotheses are grounded on the crosstalk between PP adipose tissue and tumor cells, which ultimately may induce an environment favorable to cancer progression. A better understanding of the mechanisms underlying the association between obesity and aggressive prostate cancer is warranted to gain more insight into the specific contribution of each PP adipose tissue cell type to cancer development in order to foster the development of new treatment options and, at the same time, to help identify malignancies with the worst prognosis and encourage the implementation of adjuvant chemoprevention strategies.

\section{Conclusions}

The present study, the first in human PP adipose tissue in which $\mathrm{OB} / \mathrm{OW}$ and prostate cancer-associated gene expression changes are analyzed by microarrays, provides valuable new insight on how local adipose tissue pathophysiology may favor prostate cancer. We identified altered gene expression that might impact on elements of white adipose tissue overgrowth, including anti-lipolytic, anti-apoptotic, proliferative, and mild local immunoinflammatory stimuli in PP fat of $\mathrm{OB} /$ OW subjects. The overexpression of LEP and ANGPT1 by $\mathrm{PP}$ adipose tissue in $\mathrm{OB} / \mathrm{OW}$ men may contribute 


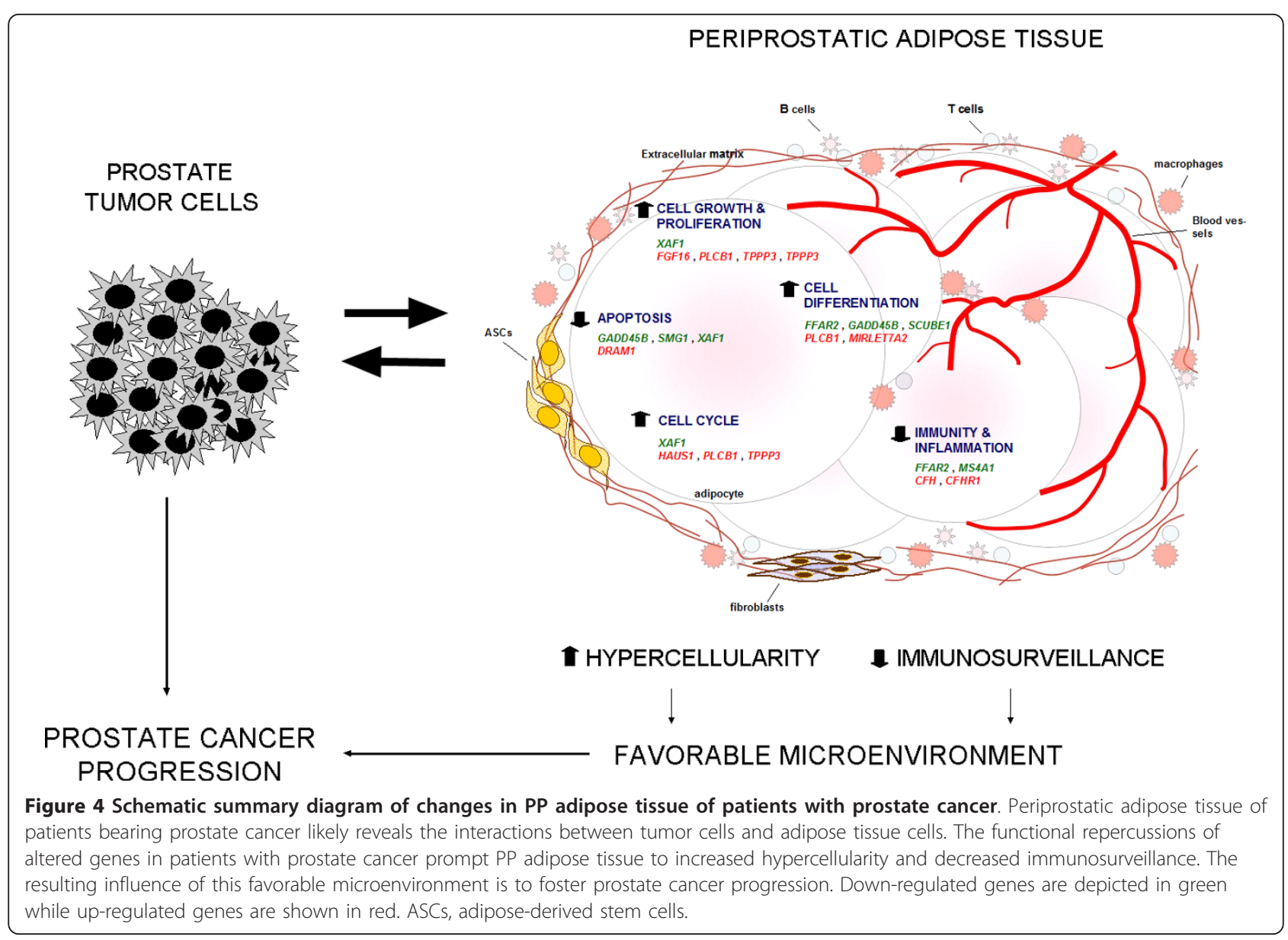

towards a favorable environment for prostate cancer progression.

The gene expression signature of PP adipose tissue from prostate cancer patients seems to provide evidence of altered gene expression across distinct cell types, with repercussions on stimuli for cell cycle regulation, cell proliferation and differentiation, as well as anti-apoptosis. Additionally, we found altered genes involved in immunological cell dormancy and reduced immunosurveillance, namely complement-related $C F H$ and $C F H R 1$ genes. Our findings suggest that the PP adipose tissue gene expression profile of both $\mathrm{OB} / \mathrm{OW}$ and prostate cancer subjects is likely to cause a local environment favorable to prostate cancer progression. Confirmation of the role of PP adipose tissue in prostate cancer progression together with untangling its mechanisms will become increasingly important in the development of adjuvant therapeutic and lifestyle measures.

\section{Additional material}

Additional file 1: Additional File 1, Table S1. Significant functions with altered networks and molecules in PP adipose tissue of OB/OW subjects.
Additional file 2: Additional File 2, Figure S1. Representative network and genes differently expressed in OB/OW versus lean in IPA analysis. Genes are represented as nodes and the biological relationship between two nodes is represented as an edge line. Uncolored genes were not identified as differently expressed in our experiment even though they are relevant to this network. Node shape indicates enzymes (rhombus), phosphatases (triangle), kinases (inverted triangle), G-protein coupled receptor (rectangle), growth factor (square), transporter (trapezoid), transcription factor (ellipse), other (circle).

Additional file 3: Additional File 3, Table S2. Significant functions with altered networks and molecules in PP adipose tissue of EPCa versus BPH subjects.

\section{Abbreviations}

BMI: body mass index; BPH: benign prostatic hyperplasia; EPCa: extraprostatic cancer; IPA: Ingenuity Pathway Analysis; OB/OW: obese/overweight; OCPCa: organ confined prostate cancer; PBS: phosphate-buffered saline; PCR: polymerase chain reaction; PP: periprostatic.

\section{Acknowledgements}

The authors acknowledge the Portuguese Foundation for Science and Technology (PTDC/SAL-FCF/71552/2006 and PTDC/SAU-ONC/112511/2009), the Research Centre on Environment, Genetics and Oncobiology of the University of Coimbra (CIMAGO 07/09), the Portuguese League Against Cancer - North Centre as well as the Spanish Institute of Science and CIBERobn. This project was partially sponsored by an unrestricted educational grant for basic research in Molecular Oncology from Novartis 
Oncology Portugal. RR was the recipient of a PhD grant from POPH/FSE (SFRH/BD/30021/2006) and a UICC-ICRETT Fellowship (ICR/10/079/2010). This work was supported in part by a project grant of the Spanish Fondo de Investigación Sanitaria (FIS PI09/02330) to GF. Funders had no role in the design, collection, analysis, and interpretation of data, in the writing of the manuscript, and in the decision to submit the manuscript for publication.

\section{Author details}

'Molecular Oncology Group, Portuguese Institute of Oncology, Ed. Laboratórios-Piso 4, Rua Dr. António Bernardino de Almeida 4200-072, Porto, Portugal. ${ }^{2}$ CBAS, Abel Salazar Biomedical Sciences Institute, University of Porto, Rua de Jorge Viterbo Ferreira no 228, 4050-313, Porto, Portugal. ${ }^{3}$ Metabolic Research Laboratory, Clínica Universidad de Navarra, Pío XII 36, 31008, Pamplona, Spain. ${ }^{4}$ LPCC - Portuguese League Against Cancer (NRNorte), Est. Interior da Circunvalação 6657, 4200-177, Porto, Portugal. ${ }^{5}$ CIBER Fisiopatología de la Obesidad y Nutrición, Instituto de Salud Carlos III, Pamplona, Spain. ${ }^{6}$ The Center for Applied Genomics, Hospital for Sick Children, MaRS Centre - East Tower 101 College Street, Room 15-705, Toronto, Ontario, M5G 1L7, Canada. 'Urology Department, Porto Hospital Centre, Largo Prof. Abel Salazar 4099-001, Porto, Portugal. ${ }^{8}$ Urology Department, D. Pedro V Military Hospital, Av. da Boavista 4150-113, Porto, Portugal. ${ }^{9}$ Urology Department, Portuguese Institute of Oncology, Rua Dr. António Bernardino de Almeida 4200-072, Porto, Portugal. ${ }^{10}$ Urology Department, S. João Hospital, Al. Prof. Hernâni Monteiro 4200 - 319, Porto, Portugal. ${ }^{11}$ CEBIMED, Faculty of Health Sciences of Fernando Pessoa University, 4200-150, Porto, Portugal. ${ }^{12}$ Department of Endocrinology \& Nutrition, Clínica Universidad de Navarra, Pío XII 36, 31008, Pamplona, Spain.

\section{Authors' contributions}

$\mathrm{RR}, \mathrm{CM}, \mathrm{VCa}, \mathrm{VCu}$ and AR performed most of the experiments. PH performed the microarray statistical analysis and edited the manuscript. AF, PP, CL, FL, AM, VS, JS-M, JO and FP collected adipose tissue and clinicopathological patient information and edited the manuscript. RR and RM performed the statistical analysis. RR, VCa, JG-A, RM and GF designed the experiments and edited the manuscript. RR and GF obtained the funding for the project. All authors read and approved the final manuscript.

\section{Competing interests}

The authors declare that they have no competing interests.

Received: 27 April 2012 Accepted: 25 September 2012 Published: 25 September 2012

\section{References}

1. Boyle P, Ferlay J: Cancer incidence and mortality in Europe, 2004. Ann Oncol 2005, 16:481-488.

2. Calle EE, Rodriguez C, Walker-Thurmond K, Thun MJ: Overweight, obesity, and mortality from cancer in a prospectively studied cohort of U.S. adults. N Engl J Med 2003, 348:1625-1638.

3. Freedland SJ, Banez LL, Sun LL, Fitzsimons NJ, Moul JW: Obese men have higher-grade and larger tumors: an analysis of the duke prostate center database. Prostate Cancer Prostatic Dis 2009, 12:259-263.

4. van Kruijsdijk RC, van der Wall E, Visseren FL: Obesity and cancer: the role of dysfunctional adipose tissue. Cancer Epidemiol Biomarkers Prev 2009, 18:2569-2578.

5. Cheng L, Darson MF, Bergstralh EJ, Slezak J, Myers RP, Bostwick DG: Correlation of margin status and extraprostatic extension with progression of prostate carcinoma. Cancer 1999, 86:1775-1782.

6. van Roermund JG, Hinnen KA, Tolman CJ, Bol GH, Witjes JA, Bosch JL, Kiemeney LA, van Vulpen M: Periprostatic fat correlates with tumour aggressiveness in prostate cancer patients. BJU Int 2011, 107:1775-1779.

7. Finley DS, Calvert VS, Inokuchi J, Lau A, Narula N, Petricoin EF, Zaldivar F, Santos R, Tyson DR, Ornstein DK: Periprostatic adipose tissue as a modulator of prostate cancer aggressiveness. J Urol 2009, 182:1621-1627.

8. Ribeiro RJ, Monteiro CP, Cunha VF, Azevedo AS, Oliveira MJ, Monteiro R, Fraga AM, Principe P, Lobato C, Lobo F, Morais A, Silva V, SanchesMagalhães J, Oliveira J, Guimarães JT, Lopes CM, Medeiros RM: Tumor celleducated periprostatic adipose tissue acquires an aggressive cancerpromoting secretory profile. Cell Physiol Biochem 2012, 29:233-240.

9. Ribeiro R, Monteiro C, Cunha V, Oliveira MJ, Freitas M, Fraga A, Principe P, Lobato C, Lobo F, Morais A, Silva V, Sanches-Magalhães J, Oliveira J, Pina F,
Mota-Pinto A, Lopes C, Medeiros R: Human periprostatic adipose tissue promotes prostate cancer aggressiveness in vitro. J Exp Clin Cancer Res 2012, 31:32

10. Fruhbeck G, Gomez-Ambrosi J: Control of body weight: a physiologic and transgenic perspective. Diabetologia 2001, 46:143-172.

11. Gomez-Ambrosi J, Catalan V, Diez-Caballero A, Martinez-Cruz LA, Gil MJ, Garcia-Foncillas J, Cienfuegos JA, Salvador J, Mato JM, Fruhbeck G: Gene expression profile of omental adipose tissue in human obesity. FASEB $J$ 2004, 18:215-217.

12. Irizarry RA, Bolstad BM, Collin F, Cope LM, Hobbs B, Speed TP: Summaries of Affymetrix GeneChip probe level data. Nucleic Acids Res 2003, 31:e15.

13. Smyth GK: Linear models and empirical bayes methods for assessing differential expression in microarray experiments. Stat Appl Genet Mol Biol 2004, 3:Article3.

14. Reiner-Benaim A, Yekutieli D, Letwin NE, Elmer Gl, Lee NH, Kafkafi N, Benjamini Y: Associating quantitative behavioral traits with gene expression in the brain: searching for diamonds in the hay. Bioinformatics 2007, 23:2239-2246.

15. Neville MJ, Collins JM, Gloyn AL, McCarthy MI, Karpe F: Comprehensive human adipose tissue mRNA and microRNA endogenous control selection for quantitative real-time-PCR normalization. Obesity (Silver Spring) 2011, 19:888-892.

16. Catalan V, Gomez-Ambrosi J, Rotellar F, Silva C, Rodriguez A, Salvador J, Gil MJ, Cienfuegos JA, Fruhbeck G: Validation of endogenous control genes in human adipose tissue: relevance to obesity and obesityassociated type 2 diabetes mellitus. Horm Metab Res 2007, 39:495-500.

17. Catalan V, Gomez-Ambrosi J, Rodriguez A, Ramirez B, Rotellar F, Valenti V, Silva C, Gil MJ, Fernandez-Real JM, Salvador J, Fruhbeck G: Increased levels of calprotectin in obesity are related to macrophage content. Impact on inflammation and effect of weight loss. Mol Med 2011, 17:1157-1167.

18. Valastyan S, Weinberg RA: Tumor metastasis: molecular insights and evolving paradigms. Cell 2011, 147:275-292.

19. Serradeil-Le Gal C, Lafontan M, Raufaste D, Marchand J, Pouzet B, Casellas P, Pascal M, Maffrand JP, Le Fur G: Characterization of NPY receptors controlling lipolysis and leptin secretion in human adipocytes. FEBS Lett 2000, 475:150-156.

20. Fruhbeck $G$, Aguado $M$, Martinez JA: In vitro lipolytic effect of leptin on mouse adipocytes: evidence for a possible autocrine/paracrine role of leptin. Biochem Biophys Res Commun 1997, 240:590-594.

21. Aversa A, Caprio M, Antelmi A, Armani A, Brama M, Greco EA, Francomano D, Calanchini M, Spera G, Di Luigi L, Rosano GM, Lenzi A, Migliaccio S, Fabbri A: Exposure to phosphodiesterase type 5 inhibitors stimulates aromatase expression in human adipocytes in vitro. I Sex Med 2011, 8:696-704

22. Baulande $S$, Lasnier $F$, Lucas $M$, Pairault J: Adiponutrin, a transmembrane protein corresponding to a novel dietary- and obesity-linked mRNA specifically expressed in the adipose lineage. J Biol Chem 2001, 276:33336-33344.

23. Wang Y, Botolin D, Xu J, Christian B, Mitchell E, Jayaprakasam B, Nair MG, Peters JM, Busik JV, Olson LK, Jump DB: Regulation of hepatic fatty acid elongase and desaturase expression in diabetes and obesity. $J$ Lipid Res 2006, 47:2028-2041.

24. Fullerton MD, Hakimuddin F, Bakovic M: Developmental and metabolic effects of disruption of the mouse CTP:phosphoethanolamine cytidylyltransferase gene (Pcyt2). Mol Cell Biol 2007, 27:3327-3336.

25. Dallabrida SM, Zurakowski D, Shih SC, Smith LE, Folkman J, Moulton KS, Rupnick MA: Adipose tissue growth and regression are regulated by angiopoietin-1. Biochem Biophys Res Commun 2003, 311:563-571.

26. Hu Z, Chen L, Zhang J, Li T, Tang J, Xu N, Wang X: Structure, function, property, and role in neurologic diseases and other diseases of the sHsp22. J Neurosci Res 2007, 85:2071-2079.

27. Sun Z, Cheng Z, Taylor CA, McConkey BJ, Thompson JE: Apoptosis induction by elF $5 \mathrm{~A} 1$ involves activation of the intrinsic mitochondrial pathway. J Cell Physiol 2010, 223:798-809.

28. Sierra-Honigmann MR, Nath AK, Murakami C, Garcia-Cardena G, Papapetropoulos A, Sessa WC, Madge LA, Schechner JS, Schwabb MB, Polverini PJ, Flores-Riveros JR: Biological action of leptin as an angiogenic factor. Science 1998, 281:1683-1686.

29. Joo HJ, Kim H, Park SW, Cho HJ, Kim HS, Lim DS, Chung HM, Kim I, Han YM, Koh GY: Angiopoietin-1 promotes endothelial differentiation 
from embryonic stem cells and induced pluripotent stem cells. Blood 2011, 118:2094-2104.

30. Park J, Scherer PE: Leptin and cancer: from cancer stem cells to metastasis. Endocr Relat Cancer 2011, 18:C25-29.

31. Yang K, Guan H, Arany E, Hill DJ, Cao X: Neuropeptide $Y$ is produced in visceral adipose tissue and promotes proliferation of adipocyte precursor cells via the Y1 receptor. FASEB J 2008, 22:2452-2464.

32. Nieman KM, Kenny HA, Penicka CV, Ladanyi A, Buell-Gutbrod R, Zillhardt MR, Romero IL, Carey MS, Mills GB, Hotamisligil GS, Yamada SD, Peter ME, Gwin K, Lengyel E: Adipocytes promote ovarian cancer metastasis and provide energy for rapid tumor growth. Nat Med 2011, 17:1498-1503.

33. Ribeiro R, Lopes C, Medeiros R: The link between obesity and prostate cancer: the leptin pathway and therapeutic perspectives. Prostate Cancer Prostatic Dis 2006, 9:19-24.

34. Price RS, Cavazos DA, De Angel RE, Hursting SD, Degraffenried LA: Obesityrelated systemic factors promote an invasive phenotype in prostate cancer cells. Prostate Cancer Prostatic Dis 2012, 15:135-143.

35. Harvey $A E$, Lashinger $L M$, Hursting $S D$ : The growing challenge of obesity and cancer: an inflammatory issue. Ann N Y Acad Sci 2011, 1229:45-52.

36. Ribeiro R, Araujo A, Lopes C, Medeiros R: Immunoinflammatory mechanisms in lung cancer development: is leptin a mediator? J Thorac Oncol 2007, 2:105-108

37. Wheway J, Mackay CR, Newton RA, Sainsbury A, Boey D, Herzog H, Mackay F: A fundamental bimodal role for neuropeptide $\mathrm{Y} 1$ receptor in the immune system. J Exp Med 2005, 202:1527-1538.

38. Thompson C, Cloutier A, Bosse Y, Poisson C, Larivee P, McDonald PP, Stankova J, Rola-Pleszczynski M: Signaling by the cysteinyl-leukotriene receptor 2. Involvement in chemokine gene transcription. J Biol Chem 2008, 283:1974-1984

39. Simopoulos AP: Genetic variants in the metabolism of omega- 6 and omega-3 fatty acids: their role in the determination of nutritional requirements and chronic disease risk. Exp Biol Med (Maywood) 2010, 235:785-795.

40. Maier B, Ogihara T, Trace AP, Tersey SA, Robbins RD, Chakrabarti SK, Nunemaker CS, Stull ND, Taylor CA, Thompson JE, Dondero RS, Lewis EC, Dinarello CA, Nadler JL, Mirmira RG: The unique hypusine modification of elF5A promotes islet beta cell inflammation and dysfunction in mice. J Clin Invest 2010, 120:2156-2170.

41. Hoon Kim J, Lee SY, Myung SC, Kim YS, Kim TH, Kim MK: Clinical significance of the leptin and leptin receptor expressions in prostate tissues. Asian J Androl 2008, 10:923-928.

42. Wurmbach JH, Hammerer P, Sevinc S, Huland H, Ergun S: The expression of angiopoietins and their receptor Tie- 2 in human prostate carcinoma. Anticancer Res 2000, 20:5217-5220.

43. Satoh N, Yamada Y, Kinugasa Y, Takakura N: Angiopoietin-1 alters tumor growth by stabilizing blood vessels or by promoting angiogenesis. Cancer Sci 2008, 99:2373-2379.

44. O'Carroll SJ, Mitchell MD, Faenza I, Cocco L, Gilmour RS: Nuclear PLCbeta1 is required for 3T3-L1 adipocyte differentiation and regulates expression of the cyclin D3-cdk4 complex. Cell Signal 2009, 21:926-935.

45. Zhou W, Wang X, Li L, Feng X, Yang Z, Zhang W, Hu R: Depletion of tubulin polymerization promoting protein family member 3 suppresses HeLa cell proliferation. Mol Cell Biochem 2010, 333:91-98,

46. Uehara R, Nozawa RS, Tomioka A, Petry S, Vale RD, Obuse C, Goshima G: The augmin complex plays a critical role in spindle microtubule generation for mitotic progression and cytokinesis in human cells. Proc Natl Acad Sci USA 2009, 106:6998-7003.

47. Nazarenko I, Rana S, Baumann A, McAlear J, Hellwig A, Trendelenburg M, Lochnit G, Preissner KT, Zoller M: Cell surface tetraspanin Tspan8 contributes to molecular pathways of exosome-induced endothelial cell activation. Cancer Res 2010, 70:1668-1678.

48. Konishi M, Mikami T, Yamasaki M, Miyake A, Itoh N: Fibroblast growth factor-16 is a growth factor for embryonic brown adipocytes. J Biol Chem 2000, 275:12119-12122.

49. Wang J, Gu Q, Li M, Zhang W, Yang M, Zou B, Chan S, Qiao L, Jiang B, Tu S, Ma J, Hung IF, Lan HY, Wong BC: Identification of XAF1 as a novel cell cycle regulator through modulating $\mathrm{G}(2) / \mathrm{M}$ checkpoint and interaction with checkpoint kinase 1 in gastrointestinal cancer. Carcinogenesis 2009, 30:1507-1516.
50. Cho HJ, Park SM, Hwang EM, Baek KE, Kim IK, Nam IK, Im MJ, Park SH, Bae S, Park JY, Yoo J: Gadd45b mediates Fas-induced apoptosis by enhancing the interaction between $\mathrm{p} 38$ and retinoblastoma tumor suppressor. J Biol Chem 2010, 285:25500-25505.

51. Arora V, Cheung HH, Plenchette S, Micali OC, Liston P, Korneluk RG: Degradation of survivin by the X-linked inhibitor of apoptosis (XIAP)XAF1 complex. J Biol Chem 2007, 282:26202-26209.

52. Crighton D, Wilkinson S, O'Prey J, Syed N, Smith P, Harrison PR, Gasco M, Garrone O, Crook T, Ryan KM: DRAM, a p53-induced modulator of autophagy, is critical for apoptosis. Cell 2006, 126:121-134.

53. Sun T, Fu M, Bookout AL, Kliewer SA, Mangelsdorf DJ: MicroRNA let-7 regulates 3T3-L1 adipogenesis. Mol Endocrinol 2009, 23:925-931.

54. Yang TT, Yu RY, Agadir A, Gao GJ, Campos-Gonzalez R, Tournier C, Chow CW: Integration of protein kinases mTOR and extracellular signalregulated kinase 5 in regulating nucleocytoplasmic localization of NFATc4. Mol Cell Biol 2008, 28:3489-3501.

55. Hirano T, Morii H, Nakazawa K, Murakami D, Yamashita A, Asahi J, Orimo H, Tamae K, Tokura Y: Enhancement of adipogenesis induction by conditioned media obtained from cancer cells. Cancer Lett 2008 , 268:286-294

56. Wilczek E, Rzepko R, Nowis D, Legat M, Golab J, Glab M, Gorlewicz A, Konopacki F, Mazurkiewicz M, Sladowski D, Gornicka B, Wasiutynski A, Wilczynski GM: The possible role of factor $\mathrm{H}$ in colon cancer resistance to complement attack. Int J Cancer 2008, 122:2030-2037.

57. Choy LN, Spiegelman BM: Regulation of alternative pathway activation and C3a production by adipose cells. Obes Res 1996, 4:521-532.

58. Tedder TF, Engel P: CD20: a regulator of cell-cycle progression of $B$ lymphocytes. Immunol Today 1994, 15:450-454.

59. Nilsson NE, Kotarsky K, Owman C, Olde B: Identification of a free fatty acid receptor, FFA2R, expressed on leukocytes and activated by short-chain fatty acids. Biochem Biophys Res Commun 2003, 303:1047-1052.

60. Gunzel D, Stuiver M, Kausalya PJ, Haisch L, Krug SM, Rosenthal R, Meij IC, Hunziker W, Fromm M, Muller D: Claudin-10 exists in six alternatively spliced isoforms that exhibit distinct localization and function. J Cell Sci 2009, 122:1507-1517.

Pre-publication history

The pre-publication history for this paper can be accessed here: http://www.biomedcentral.com/1741-7015/10/108/prepub

doi:10.1186/1741-7015-10-108

Cite this article as: Ribeiro et al:: Obesity and prostate cancer: gene expression signature of human periprostatic adipose tissue. BMC Medicine 2012 10:108.

\section{Submit your next manuscript to BioMed Central and take full advantage of:}

- Convenient online submission

- Thorough peer review

- No space constraints or color figure charges

- Immediate publication on acceptance

- Inclusion in PubMed, CAS, Scopus and Google Scholar

- Research which is freely available for redistribution

Submit your manuscript at www.biomedcentral.com/submit
C BioMed Central 